\title{
THE PERMISSIBILITY OF LIMITING RIGHTS AND FREEDOMS IN THE EUROPEAN AND NATIONAL LEGAL SYSTEM DUE TO HEALTH PROTECTION
}

\author{
Robert Tabaszewski*
}

\begin{abstract}
This article concerns the permissibility of limiting human rights and freedoms in European and national systems due to the protection of individual and public health. The author's goal was to analyse the current practice in the application of human rights limitation clauses in the European system of human rights protection. This is an important issue because the practice of limitation and margin of appreciation enjoyed by the member states of the Council of Europe is subject to scrutiny by means of complaints addressed to the European Court of Human Rights in Strasbourg, which examines the correct application of individual limitation clauses contained in the 1950 Convention. Human health is one of the main prerequisites for which it is possible to limit other human rights and freedoms. In the context of numerous epidemiological threats and natural disasters of a cross-border nature, assessing rights and freedoms becomes one of the most important issues in the field of public international law, constitutional law and public health law. Against the background of existing solutions in the universal system, the practice of the member states of the European Union and the Council of Europe was examined by comparing it with the views of the doctrine and the results of my research.
\end{abstract}

Keywords: legal limitations, public health, individual health, human rights and freedoms, international law, domestic law, environmental health law

Ph.D. Robert Tabaszewski, LL.M., Department of Human Rights and Humanitarian Law, Faculty of Law, Canon Law and Administration, The John Paul II Catholic University of Lublin, e-mail: robert.tabaszewski@gmail.com, ORCID 0000-0002-7737-0056. 


\section{PRELIMINARY REMARKS}

Health is one of the basic values in the European system of protecting rights and freedoms ${ }^{1}$. In dogmatic and legal terms, health is most often treated as a degree of physical fitness, determined by disabilities: diseases, injuries, accidents, changes related to ageing processes or insufficient functional development in the early stages of life. Health should be understood as a certain amount of strength, well-being and the degree of biological, mental and social preparation that is achievable for a given individual in the most favourable conditions ${ }^{2}$. According to Preamble to the WHO Constitution of 1948, health is a state of complete physical, mental and social well-being and not merely the absence of disease or infirmity ${ }^{3}$. Very convergent definitions of health could be found in EU documents. Full health gives people the opportunity to fully develop social activity on various planes of life, including allowing them to perform ordinary, everyday social roles and exercise other human rights ${ }^{4}$.

Although a separate human right to health is not formally included in the catalogue of the Convention for the Protection of Human Rights and Fundamental Freedoms (ECHR) ${ }^{5}$ of 1950 , health is subject to spe-

1 Henriette Roscam Abbing, "Health Law \& the European Union," European Journal of Health Law 1994, No. 1: 123-126; Michael Krennerich, "The Human Right to Health Fundamentals of a Complex Right," in Healthcare as a Human Rights Issue. Normative Profile, Conflicts and Implementation, eds. Sabine Klotz, Heiner Bifeldt, Martina Schmidhuber, Andreas Frewer (Bielefeld: Verlag, 2017), 29-47.

2 Janusz Opolski, Maria Miller, "Marcin Kasprzak. Komentarz do prac," Postępy Nauk Medycznych 2009, No. 4: 317-318.

3 Robert Tabaszewski, "Rola ius cogens i soft law Światowej Organizacji Zdrowia w kształtowaniu praw i wolności człowieka," in Ius cogens - soft law, dwa bieguny Prawa Międzynarodowego Publicznego. Księga dedykowana profesorowi Uniwersytetu Jagiellońskiego Kazimierzowi Lankoszowi, ed. Milena Ingelevič-Citak, Brygida Kuźniak (Kraków: Wydawnictwo Uniwersytetu Jagiellońskiego, Kraków, 2017), 390-401.

4 Dorota Kiedik, Andrzej Fal, “Zdrowie jednostki,” in Zdrowie publiczne. Podręcznik akademicki, eds. Anna Felińczak, Adam Fal (Wrocław: Akademia Medyczna im. Piastów Śląskich, 2010), 9; Talcott Parsons, Struktura spoteczna a osobowość (Państwowe Wydawnictwo Ekonomiczne: Warszawa, 1969), 150.

5 Council of Europe, European Convention on Human Rights and Fundamental Freedoms, Rome, 4 November 1950 as amended by Protocols Nos. 11 and 14 supplement- 
cial protection under a number of other provisions issued by the Council of Europe (CoE) and the European Union (EU) ${ }^{6}$. The member states of these international organisations have given health features of particular value. Without good health, a person cannot use goods and pursue other values ${ }^{7}$. In the light of international law, recognition of health as a superior value over other human rights is enabled by two concepts of limiting rights and freedoms: limitation and the margin of appreciation. The purpose of this article is to examine the functionality of these concepts by analysing the provisions of the Convention and case law. This makes it possible to check whether and to what extent public health, and health as a value of an individual, can be the basis for limiting other rights and freedoms. This is particularly important due to the growing amount of international and national case law supplementing heterogeneous provisions as well as the new endemic and pandemic threats facing European societies $^{8}$. The subject of permissibility of limitations, absent in Polish literature, also appears when analysing various obligations imposed by states on their citizens, including those related to compulsory vaccinations, creating sanitary zones free of specific substances, quarantining, ordering disclosure of specific test results, or limitations of freedom of movement and communication.

ed by Protocols Nos. 1, 4, 6, 7, 12, 13 and 16, ETS No. 5: ETS No. 009, 4: ETS No. 046, 6: ETS No. 114, 7: ETS No. 117, 12: ETS No. 177.

6 Robert Tabaszewski, "Health as a Legal Term and its Evolution in the Council of Europe's Human Rights Protection System”, Studia Etckie No. 4(2019): 583-594.

7 John Tobin, The Right to Health in International Law (Oxford: Oxford University Press, 2012), 47-48, 125-126; Eibe Riedel, "The Human Right to Health: Conceptual Foundations," in Realizing the Right to Health, ed. Andrew Clapham, Mary Robinson (Zurich: Rüfe\&Rub, 2009), 28; Theresa Murphy, Health and Human Rights (Oxford-Portland-Oregon: Hart Publishing, 2013), 23-27.

8 Roojin Habibi, Stephanie Dagron, Lawrence O. Gostin, Stefania Negri et al., "Do not violate the International Health Regulations during the COVID-19 outbreak," Lancet 29;395(2020): 664-666. 


\section{THE CONCEPT OF HUMAN RIGHTS LIMITATION IN INTERNATIONAL HUMAN RIGHTS LAW}

Limiting human rights is an important legal issue. This concept is based on the recognition that not all human rights are absolute ${ }^{9}$. In situations of conflict between the interests of an individual and those of an entire community, priority must be given to the rights of the entire community ${ }^{10}$. The concept of limitation was supported by the creators of the Universal Declaration of Human Rights (UDHR), who recognised that, in addition to the rights of a human being, every individual also has obligations to society, without which the free and full development of their personality is impossible ${ }^{11}$. In exercising their rights and freedoms, a human being is subject to restrictions set by law solely to ensure proper recognition and respect for the rights and freedoms of other individuals and solely to satisfy the legitimate requirements of morality, public order and the universal well-being of a democratic society ${ }^{12}$.

The exercising of human rights contrary to these universal values does not deserve the protection granted by United Nations (UN) and implemented by the authorities of a given country. Mutatis mutandis, human rights are not absolute in every case and do not always apply as ius infinitum $^{13}$. The provision of Article 29 of the UDHR is therefore a guarantee and aims to prevent the arbitrariness and abuse of human rights by

9 Robert Tabaszewski, Prawo do zdrowia w systemach ochrony praw cztowieka (Lublin: KUL, 2020), 83-84.

10 Luka Anđelković, "The elements of proportionality as a principle of human rights limitations," Facta Universitatis Series: Law and Politics 15, No. 3(2017): 235-244.

11 See: art. 29(3) Universal Declaration of Human Rights adopted 10 December 1948), G.A. Res. 217A (III), U.N. Doc. A/810 at 71 (1948); UN Charter and Statute of the International Court of Justice, signed on 26 June 1945 at the San Francisco Conference.

12 The person who applies for such protection will therefore not obtain it from the Human Rights Committee and other UN committees. See: art. 29(1) UDHR; Hurst Hannum, "The UDHR in National and International Law," Health and Human Rights 3, No. 2(1998): 147; Brigit Toebes, The Right to Health as a Human Right in International Law (Antwerpen: Intersentia/Hart, 1999), 36-40.

13 United Nations Human Rights Committee, Case André Brun v. France. Communication No. 1453/2006, U.N. Doc. CCPR/C/88/D/1453/2006, Geneve 2006. 
an individual ${ }^{14}$. However, it is difficult to require every individual to decide when their right has primacy over the right of another human being. Therefore, the authorities of a given state must ensure that priority is given to the applicable law or freedoms in the event of a conflict between several human rights and freedoms. In this way, through a specific process of assessing rights and freedoms, national authorities should ensure the proper functioning of the entire human rights protection system. This process is called the interpretation of the so-called limitation clauses ${ }^{15}$.

The possibility of limiting rights and freedoms is currently a normative concept recognised by international law. Most often, there are limitation clauses regarding the entire document, such as Article 4 of the International Covenant on Economic, Social and Cultural Rights (ICESCR) ${ }^{16}$. Limitation clauses prevent the collision of interests of individual values with the rights of society, in terms of both their substantive content and the permissibility of their derogations ${ }^{17}$. The use of limitation clauses knows no restrictions, neither temporal nor subjective. This means that limitations

14 Bogusław Banaszak, System ochrony praw cztowieka (Kraków: Wolters Kluwer, 2003), 42-43; Łukasz Górski, "Prawa jednostki wobec praw grupy. Konflikt czy współistnienie?," in Cztowiek - jego prawa i odpowiedzialność, ed. Robert Tabaszewski (Lublin: KUL, 2013), 27-29.

15 Nicolas Croquet, The Role and Extent of a Proportionality Analysis in the Judicial Assessment of Human Rights Limitations within International Criminal Proceedings (Leiden: Brill-Nijhoff, 2015), 286.

16 International Covenant on Economic, Social and Cultural Rights (ICESCR) (adopted 16 December 1966; entered into force 3 January 1976), UNTS 993: 3; Robert Tabaszewski, "Achieving the Sustainable Development Goals in Europe and Asia: role of regional organizations in monitoring human right to health and well-being," Ius Novum Vol. 13, No. 2(2019): 250-269.

17 In accordance with Article 19 of the Vienna Convention on the Law of Treaties, states can lodge reservations when signing, ratifying, accepting or approving a treaty, and when acceding to a treaty See: art. 2(d) of Vienna Convention on the Law of Treaties, May 23, 1969, Vienna, 1155 U.N.T.S. 331, 8 I.L.M. 679. By lodging reservations, states can completely exclude or modify the legal effects of certain provisions of a treaty that may apply to that state. These objections are referred to by international human rights law as limitation clauses and may take the form of individual clauses expressed in particular provisions. See: Tadeusz Jasudowicz, Administracja wobec praw cztowieka (Toruń: TNOiK 1996), 31-32; Idem, "Granice wymagalności międzynarodowo chronionych praw człowieka," in Prawa cztowieka i ich ochrona, eds. Bożena Gronowska (Toruń: TNOiK, 2010), 227-235. 
on the use of particular rights can be imposed due to the interests of individuals, entire communities and a state, regardless of the situation of the state and its apparatus but the ratio of the limitations imposed cannot violate the essence of the rights ${ }^{18}$. The Vienna Declaration and Programme of Action ${ }^{19}$ encourages states to consider limiting the extent of any reservations they lodge to international human rights instruments, formulating any reservations as precisely and narrowly as possible, ensuring that none is incompatible with the object and purpose of the relevant treaty and regularly reviewing any reservations with a view to withdrawing them ${ }^{20}$.

In the universal system of human rights protection, the possibility of limiting human rights is provided not only by the UDHR, but also by the International Covenant on Civil and Political Rights (ICCPR) ${ }^{21}$ and the ICESCR. Limitation of rights and freedoms is also possible in the European system, both in the CoE and EU documents. Limitation clauses have been included in the two most important CoE conventions, namely the basic version of the European Convention on Human Rights $(\mathrm{ECHR})^{22}$, and the European Social Charter (ESC) from 1961 and the European Social Charter (Revised) from $1996^{23}$. The limitation clauses contained therein constitute a model for other normative acts of a regional nature. Also, all rights contained in the Charter of Fundamental Rights of the European Union (ChoFR) 'are subject to a general limiting clause ${ }^{24}$. This determines the relative nature of the EU's fundamental rights.

18 United Nations, Economic and Social Council, Siracusa Principles on the Limitation and Derogation Provisions in the International Covenant on Civil and Political Rights, 1984 Siracusa, Italy, U.N. Doc. E/CN.4/1985/4, Annex (Siracusa Principles).

19 Vienna Declaration and Programme of Action, A/CONF.157/23, 12 July 1993.

20 See: Diego Silva, Maxwell Smith, "Limiting rights and freedoms in the context of Ebola and other public health emergencies: how the principle of reciprocity can enrich the application of the Siracusa Principles," Health and Human Rights Journal vol. 17, No. 1(2015): 52-57.

21 International Covenant on Civil and Political Rights (ICCPR) (adopted 16 December 1966; entered into force 23 March 1976), UNTS 999: 171.

22 Council of Europe, European Social Charter, ETS No. 035, Turin, 10 October 1961.

23 Council of Europe, Revised European Social Charter, as amended (ESC), ETS No. 163, Strasbourg, 3 May 1996.

24 See: Article 52(1) of the ESC. 
Detailed rules for the possibility of applying limitation by national authorities are set out in the Siracusa Principles on the Limitation and Derogation Provisions in the International Covenant on Civil and Political Rights of 1984, the Limburg Principles on the Implementation of the International Covenant on Economic, Social and Cultural Rights from $1987^{25}$ and The Maastricht Guidelines on Violations of Economic, Social and Cultural Right from $1997^{26}$. These documents set out the characteristics of limitation clauses. The clauses are characterised by a specific construction, including the use of open and vague terms, such as: "prescribed by law', 'in a democratic society' and 'public order'. A limitation clause 'includes all norms constituting the basis for limiting human rights if they condition the permissibility of interference with its legality, purposefulness or necessity of application ${ }^{27}$. Limitation clauses should be interpreted strictly, taking account of the nature and context of a given law, as well as observing the rules of friendly interpretation. None of the above limitations can be applied arbitrarily by a state ${ }^{28}$.

\section{PERMISSIBILITY OF LIMITING HUMAN RIGHTS IN THE NATIONAL SYSTEM}

National human rights protection systems also provide that rights and freedoms are not absolute ${ }^{29}$. European constitutions specify formal and material guarantees and limits as well as conditions for applying necessary

25 The Limburg Principles on the implementation of the International Covenant on Economic, Social and Cultural Rights, UN ESCOR, Commission on Human Rights, Forty-third Sess., Agenda Item 8, UN Doc. E/CN.4/1987/17, Annex (1987).

26 The Maastricht Guidelines on Violations of Economic, Social and Cultural Rights, UN Doc. E/C.12/2000/13(2000).

27 They have the mentioned characteristics that distinguish them from ex definitione limitations, derogation clauses and other methods of limiting human rights, see: Rafał Mizerski, "Granice wymagalności międzynarodowo chronionych praw człowieka," in Prawa cztowieka i ich ochrona, eds. Bożena Gronowska (Toruń: TNOiK, 2010), 234-235.

28 See: Siracusa Principles, pt. 3-8.

29 Joanna Zakolska, "Problem klauzuli ograniczającej korzystanie z praw i wolności człowieka w pracach konstytucyjnych, w poglądach doktryny i orzecznictwa Trybunału Konstytucyjnego," Przeglad Sejmowy No. 5 (2005):11-29. 
limitations on rights and freedoms. The conditions for limiting human and citizen rights are set out in the general limitation clause contained in Article 31(3) of the Constitution of the Republic of Poland ${ }^{30}$. It largely corresponds to the clauses contained in the conventions that Poland has ratified $^{31}$. In particular, the solution regarding limitation of rights and freedoms is modelled on the ECHR. This means that any limitations can be made by statute when they are necessary in a democratic state in order to: ensure its security or public order; protect the environment, public health and morals; and protect the rights and freedoms of others ${ }^{32}$. At the same time, all limits must not violate the essence of rights and freedoms underlying the entire national human rights protection system ${ }^{33}$.

National authorities can also limit rights and freedoms in the Polish system of human rights protection due to the need for human health protection, among others, thanks to the so-called judicial margin of appreciation doctrine $^{34}$. The margin of appreciation, which is referred to as a margin of discretion in European doctrine, is a relatively recent concept of interpretation of treaties in international law that has sprouted from national case law. While the scope of the meaning of each concept is slightly different, both terms are usually treated interchangeably in the Polish system of human rights protection. This doctrine is related to the activities of courts in individual human rights protection systems ${ }^{35}$. It grants freedom to nation-

30 The Constitution of the Republic of Poland, Journal of Laws 1997, No. 78, item 483, as amended.

31 Krzysztof Wojtyczek, Granice ingerencji ustawodawczej $w$ sferę praw cztowieka w Konstytucji RP (Kraków: Zakamycze, 1999), 192; Marek Piechowiak, "Klauzula limitacyjna a nienaruszalność praw i godności,” Przegląd Sejmowy No. 2 (2009): 55-77.

32 Paweł Kuczma, Prawa cztowieka w zarysie (Polkowice: Dolnośląska Wyższa Szkoła Przedsiębiorczości i Techniki, 2011), 33-34; Anna Łabno, "O ograniczenie wolności i praw cztowieka na podstawie art. 31 Konstytucji III RP," in Prawa i wolności obywatelskie w Konstytucji RP, eds. Bogusław Banaszak, Artur Preisner (Warszawa: C.H. Beck, 2002), 693-694.

33 See: Polish Constitutional Tribunal, Judgment of $12^{\text {th }}$ January 2000, sign. P 11/98, Journal of Laws 2000, No. 3, item 46, as amended.

34 Adam Wiśniewski, "W sprawie koncepcji marginesu oceny w orzecznictwie strasburskim,” Państwo i Prawo No. 2(2008): 97-104.

35 "Margin of discretion," in Encyclopedic Dictionary of International Law, eds. John Grant, Craig Barker (Oxford: OUP, 2009); Eyal Benvenisti, "Margin of appreciation, con- 
al public authorities and its representatives in applying certain norms of international law. The prevailing view in the literature is that the concept of the margin of appreciation is ' $a$ doctrine that gives national authorities a certain degree of freedom in applying the requirements of the Convention depending on specific conditions ${ }^{36}$.

The margin of appreciation doctrine recognises that a state and its officials are entitled to a degree of discretionary power, that is, free discretion in the process of interpretation and application of treaty provisions, and administrative recognition is at its source ${ }^{37}$. It is worth noting that in the universal system, the margin of appreciation doctrine is only being created. It is used by the International Court of Justice as a method of interpreting treaties, particularly in relation to human rights limitation clauses ${ }^{38}$. Appeals to the margin of appreciation are made by Human Rights Committee experts, among others, who have repeatedly examined complaints about violations of human rights to life and health. The Maastricht Guidelines on Violations of Economic, Social and Cultural Rights specify that 'states enjoy a margin of discretion in selecting the means for implementing their respective obligations' for a more complete implementation of these rights ${ }^{39}$. The concept of the margin of appreciation in the UN system can also be useful in interpreting special conventions such as the Convention on the Rights of the Child ${ }^{40}$. The convention grants every child the right to enjoy and preserve their health ${ }^{41}$. It is increasingly accepted that this

sensus, and universal standards," The New York University Journal of International Law and Politics No. 31(1999): 843-854; Yutaka Arai-Takahashi, The Margin of Appreciation Doctrine and the Principle of Proportionality in the Jurisprudence of the ECtHR, (Antwerpen-Oxford-New York: Intersentia, 2001), 199.

36 See: Marek Antoni Nowicki, Stownik Europejskiej Konwencji Praw Cztowieka (Warszawa: Wolters Kluwer Polska, 2009), 315-16.

37 Jan Zimmermann, Prawo administracyjne (Kraków: Zakamycze, 2006), 309-313.

38 Yuval Shany, “Toward a General Margin of Appreciation Doctrine in International Law?," European Journal of International Law No. 16(2005): 907-940.

39 See: Maastricht Guidelines, pt 8.

40 Convention on the Rights of the Child adopted and opened for signature, ratification and accession by General Assembly resolution 44/25 of 20, UN Doc. No. 27531 November 1989.

41 See: John Tobin, The Right to Health in International Law, 178-179. 
doctrine can also be applied to conciliation and arbitration courts, whose subject of activity may relate to public health ${ }^{42}$.

In regional systems, the concept of the margin of appreciation first appeared in the jurisprudence of the European Court of Human Rights in Strasbourg (ECtHR) in the first decade of its operation. The margin of appreciation doctrine was recognised and reinforced only in 1979. The culmination of this process were changes, which were proposed in Protocol 15, supplementing the ECHR Preamble with the margin of appreciation doctrine ${ }^{43}$. It is a specific structure created for the purposes of dialogue with national authorities. It allows the Strasbourg Court 'to take account of the discretion of national authorities in the process of monitoring the application of the Convention and its protocols by States Parties' ${ }^{34}$. The material scope of the margin of appreciation is essentially left to the discretion of national public authorities, although the degree of this 'discretion' varies depending on the right to be protected. In the case of health, we deal with an exceptionally strong law, subject to many protection mechanisms ${ }^{45}$.

The significance of this institution is also expressed in the fact that the principle of the margin of appreciation, in the context of health protection by national authorities, allows certain values to be prioritised. It modifies the process of interpretation and application of the ECHR, and also performs the role of modifying the manner in which the court supervises the scope of compliance with binding legal norms by states ${ }^{46}$. In general, the margin is only applicable to a part of a given norm, while the entire discre-

42 See: Judgment of 12 December 1996, Oil Platforms (Islamic Republic of Iran v. United States of America); Judgment of 31 March 2004, Avena and Other Mexican Nationals.

43 See: Adam Wiśniewski, Koncepcja marginesu oceny w orzecznictwie Europejskiego Trybunatu Praw Cztowieka (Gdańsk: Wydawnictwo Uniwersytetu Gdańskiego, 2008), 25.

44 Idem, "Uwagi o zastosowaniu koncepcji marginesu oceny w prawie międzynarodowym," in Prawo międzynarodowe i wspólnotowe wobec wyzwań wspótczesnego świata, ed. Elżbieta Dynia (Rzeszów: Wydawnictwo Uniwersytetu Rzeszowskiego, 2009), 330.

45 See: Julia Kapelańska-Pręgowska, "Koncepcja tzw. marginesu oceny w orzecznictwie Europejskiego Trybunału Praw Czowieka," in Państwo i Prawo No. 12, 2007: 88; Jan Kratochvíl, "The inflation of the margin of appreciation by the European Court of Human Rights," Netherlands Quarterly of Human Rights No. 3(2011): 326-328.

46 Adam Wiśniewski, "Uwagi”, 335-336. 
tionary process is judicially conditioned and supervised by the $\mathrm{ECtHR}^{47}$. National authorities are also obliged to prove (onus probandi) and clarify all circumstances of facts and provide reasons justifying the use of the level of discretion in the case of preference for standards regarding, for example, health protection ${ }^{48}$.

\section{HEALTH AS A PREREQUISITE FOR LIMITING RIGHTS AND FREEDOMS IN THE EUROPEAN SYSTEM}

In the European system for the protection of human rights, individual limitation clauses contain direct references to health as a condition limiting the possibility of applying other rights and freedoms. They are contained in $\mathrm{EU}$ documents and the CoE conventions ${ }^{49}$. This is very important for member states, such as Poland, because state authorities do not have complete freedom in modifying the content of the rights and freedoms of their citizens under the guise of the need to protect human health, and can only do so under the conditions specified in the documents of both international organisations. This is important in the event of a collision between at least two legally protected goods; some goods, such as health, are given special significance. As national authorities apply individual limitations, caused in particular by the need to protect human health in the universal dimension, other rights or freedoms (or several rights and freedoms) are restricted. The basis for such restrictions may be the obligation to protect health or morals, which was imposed on national authorities by the provisions of the original version of the ECHR expressed in Article 8(9),

47 Oren Gross, Fionnuala Ní Aoláin, "From Discretion to Scrutiny: Revisiting the Application of the Margin of Appreciation Doctrine in the Context of Article 15 of the European Convention on Human Rights," in Human Rights Quarterly No. 3(2001):625-649.

48 ECtHR, Case Handyside v. The United Kingdom, application no. 5493/72; ECtHR, Case Haase v. Germany, application no. 11057/02.

49 See: Steve Peers, "Taking Rights Away? Limitations and Derogations," in The European Union Charter of Fundamental Rights, ed. Steve Peers, Angela Ward (Oxford-Portland-Oregon: Hart Publishing, 2004), 143-148. 
Article 10 and Article 11 of the Convention and Article 2 of Additional Protocol No. 4 to the 1963 Convention $^{50}$.

The European Social Charter (ESC) also provides for the possibility of limiting rights and freedoms for the protection of public interest, national security, public health, or morals ${ }^{51}$. The permissibility of limiting the rights specified in the ESC has been expressed in Article 31 of the ESC. Due to the need for health protection, it is possible to limit certain categories of rights and the limitations allowed in accordance with the provisions of the ESC in relation to the rights and obligations established in it may not be used for any purpose other than the one for which they were envisaged $^{52}$. In accordance with the principle of equality adopted in the ESC (Revised), which consequently introduces a prohibition of discrimination and the obligation of equal treatment, the guarantee rule ensures the exercise of the right laid down in the ESC, which must be ensured without any discrimination arising from the enumerated reasons listed, including the state of health ${ }^{53}$. As can be seen, unlike the provisions of the 1950 Convention, which uses the concept of health, the ESC (Revised) allows national authorities to limit rights and freedoms not due to health, but due to public health, which concerns entire communities, not individuals. In practice, both concepts, health and public health, are blurred because the ECtHR narrows the concept of health to public health. Individual health does not appear in the text of the Convention and must be combined with the

50 See: ECtHR, Case Olsson v. Sweden, application no. 10465/83.

51 See: Article 31 ESC(Revised).

52 See: art. 31(1) ESC „The rights and principles set forth in Part I when effectively realised, and their effective exercise as provided for in Part II, shall not be subject to any restrictions or limitations not specified in those parts, except such as are prescribed by law and are necessary in a democratic society for the protection of the rights and freedoms of others or for the protection of public interest, national security, public health, or morals The Commitee of Independent Experts, restrictions on the application of ESC regulations can be justified only if the following requirements are met: necessary protection of rights and freedoms or protection of public security, national security, public health. See: European Social Charter: Conclusions XIV-2 - Articles 1, 2, 3, 4, 9, 10, 15 and Articles 1 to 4 of the 1988: Norway, 220-222.

53 See: Tadeusz Jasudowicz, "Limits of Enjoyment of Human Rights in the System of the European Social Charter," Polish Review of International and European Law" vol. 6, No. 1(2017): 49-70. 
right to life ${ }^{54}$. It also means that in certain situations, CoE member states are required to suspend other human rights when public health is at risk. Mutatis mutandis, the lack of a proper response by state authorities may be considered a violation of Article 2 in the general dimension and result in liability for violation of the Convention.

Imposing limitations by national authorities due to the need 'for the protection of health or morals' is difficult because, as already noted, a legally binding definition of health is not included in the ECHR or in any CoE Convention ${ }^{55}$. Therefore, my analysis of the court's case law has shown that the ECtHR is based on functional theories regarding health protection. In light of this, being healthy is being able to perform everyday activities $^{56}$. This opinion therefore stands in partial opposition to the holistic concept of health provided by the World Health Organization (WHO) ${ }^{57}$. According to ECtHR judges, health is an attribute of every human being, but the court recognised health as a component of public health of special importance only in individual rulings ${ }^{58}$.

It is worth noting that health is only one of several purposes for which the ECHR allows a state to limit certain human rights and freedoms. In Articles 8-11 of the ECHR and Article 2 of Additional Protocol No. 4, although health occurs together with the prerequisite for the protection of morals, it functions as an independent and sufficient premise for limiting five convention rights and freedoms: the right to respect for private and family life ${ }^{59}$; freedom of thought, conscience and religion ${ }^{60}$; freedom of expression ${ }^{61}$; freedom of assembly and association ${ }^{62}$; and freedom of movement ${ }^{63}$. Although the right to health, in both public and individual

\footnotetext{
54 Art. 2 ECHR.

55 Robert Tabaszewski, Prawo do zdrowia, 106-107.

56 Mildred Blaxter, Zdrowie (Warszawa: Wydawnictwo Sic!, 2009), 15.

57 John Charles, "Origins, history, and achievements of the World Health Organization," The British Medical Journal vol. 4, No. 2(1968), 293-296.

58 Robert Tabaszewski, Prawo do zdrowia, 83-84.

59 See: art. 8(2) ECoHR.

60 See: art. 9(2) ECoHR.

61 See: art. 10(2) ECoHR.

62 See: art. 11(2) ECoHR.

63 See: art. 2(3) of the Protocol No. 4 ECoHR.
} 
dimensions, is in close interaction with all these human rights, the ECHR regulations provide for the primacy of health over other goods ${ }^{64}$.

The human right to privacy is the first of the rights subject to individual limitation contained in the ECHR's catalogue. Undoubtedly, the state of human health, as a rule, should be an individual's personal and private information, which should be kept confidential at all levels of prevention, treatment, care and support ${ }^{65}$. Therefore, the content of the Convention relating to the possibility of limiting the right to privacy is categorical. It acknowledges that 'there shall be no interference by a public authority with the exercise of this right except such as is in accordance with the law and is necessary in a democratic society in the interests of national security, public safety or the economic well-being of the country, for the prevention of disorder or crime, for the protection of health or morals, or for the protection of the rights and freedoms of others' 66 . Using the concept of 'health protection' in Article $8(2)$, the Convention, therefore, allows limiting privacy only where medical or preventive care necessary for maintaining health in the general dimension is provided.

The other two rights that may be limited on the grounds of human health protection are freedom of thought, conscience and religion (Article 9) and freedom of expression (Article 10). The freedom to manifest religion or beliefs may collide with the right to health, for example, in the event of a religious group preventing sanitary or epidemiological control ordered by the authorities, or a breach of its information obligations regarding compulsory vaccinations or check-ups by a community. In the light of the ECHR, this freedom 'shall be subject only to such limitations as are prescribed by law and are necessary in a democratic society in the interests of public safety for the protection of public order, health or morals, or for the protection of the rights and freedoms of others ${ }^{37}$.

64 Bartłomiej Latos, Klauzula derogacyjna i limitacyjna w Europejskiej Konwencji o ochronie praw cztowieka i podstawowych wolności (Warszawa: Wydawnictwo Sejmowe, 2008), 8, 194-199.

65 Adeline M. Connelly, "Problems of Interpretation of Article 8 of the European Convention on Human Rights," International \& Comparative Law Quarterly vol. 35, No. 3(1986): 567-593.
66 Art. 8(2) ECoHR.
${ }_{67}$ Art. 9(2) ECoHR. 
Also, exercising freedom of expression 'may be subject to such formalities, conditions, restrictions or penalties as are prescribed by law and are necessary in a democratic society, in the interests of national security, territorial integrity or public safety, for the prevention of disorder or crime, for the protection of health or morals, for the protection of the reputation or rights of others, for preventing the disclosure of information received in confidence, or for maintaining the authority and impartiality of the judiciary ${ }^{68}$. As can be seen, health is only one of many grounds for limiting freedom of expression by a state. The potential limitation of freedom of expression due to health protection is, however, considered controversial in the literature, as it potentially limits scientific debate $^{69}$. Therefore, any limitation should only be made exceptionally, for example, to prevent the spread of false content in order to protect the population at risk of a global pandemic or ecological disaster ${ }^{70}$.

Another individual clause allowing limitation due to health protection concerns freedom of assembly and association. Article 11 of the Convention obliges the authorities of a given state that "no restrictions shall be placed on the exercise of these rights other than such as are prescribed by law and are necessary in a democratic society in the interests of national security or public safety, for the prevention of disorder or crime, for the protection of health or morals or for the protection of the rights and freedoms of others. This article shall not prevent the imposition of lawful restrictions on the exercise of these rights by members of the armed forces, of the police or of the administration of the State ${ }^{71}$. It is recognised in the literature that restricting freedom of assembly is possible if there is a justified risk to the health of even one person, and the state of danger cannot be avoided in any other way.

The last of the rights subject to individual limitation, which, however, has not been included in the original text of the ECHR, is human freedom of movement. The permissibility of limiting freedom of movement, due to a prerequisite for health protection, among others, is possible thanks to

68 Art. 10(2) ECoHR.

69 Varun M. Malhotra, "Freedom of expression and health: is the association causal?," Lancet vol. 388, No. 10044(2016): 561.

70 Victoria Sutton, "Emergencies, disasters, conflicts, and human rights," in Advancing the human right to health, eds. José M. Zuniga, Stephen P. Marks, Lawrence O. Gostin (Oxford: Oxford University Press, 2013), 379-388.

71 Art. 11(2) ECoHR. 
the inclusion of Additional Protocol No. 4 to the ECHR by CoE member states in 1963. Article 2(3) of this protocol provides that 'no restrictions shall be placed on the exercise of these rights other than such as are in accordance with law and are necessary in a democratic society in the interests of national security or public safety, for the maintenance of public order, for the prevention of crime, for the protection of health or morals, or for the protection of the rights and freedoms of others ${ }^{32}$. This provision is very important because it allows a state to restrict freedom of movement or impose isolation due to a risk of infectious diseases. In such a situation, state authorities are required to justify the reasons for applying restrictions on the free movement of patients and medical staff.

The possibility of limiting fundamental rights on the grounds of health protection is provided for in the Charter of Fundamental Rights ${ }^{73}$, which also recognises a separate right to health care and treatment under the conditions laid down by national provisions ${ }^{74}$. In the EU system, all restrictions on exercising fundamental rights must be provided for by law and respect the essence of these rights and freedoms ${ }^{75}$. Any limitation may be introduced subject to the principle of proportionality and only when it is necessary and genuinely meets the objectives of the general EU interest or the need to protect the rights and freedoms of others. This is because the ChoFR does not recognise any rights and freedoms as absolute ${ }^{76}$. As a rule, all rights contained in the ChoFR are, therefore, subject to mechanisms of their limitation and even derogation in situations of particular threat to the existence of a nation or state ${ }^{77}$. The possibility of limiting fundamental rights due to the need for human health protection is also provided for by

72 Art. 2(3) of the Protocol No. 4 ECoHR.

73 European Union: Charter of Fundamental Rights of the European Union. Official Journal of the European Communities, C 364, 18 December 2000.

74 See: art. 35 of ChoFR.

75 See: Dimitris Triantafyllou, "The European Charter of Fundamental Rights and the "Rule of Law": Restricting Fundamental Rights by Reference," Common Market Law Review No. 1(2002): 53.

76 Art. 52(1) ChoFR.

77 Elżbieta Morawska, "Prawa konstytucyjne człowieka i obywatela w Rzeczypospolitej Polskiej a prawa podstawowe Unii Europejskiej. Analiza porównawcza,” Przegląd Sejmowy No. 1(2009): 41. 
the Court of Justice of the EU. However, it is the ECHR rulings that remain the most important for determining the scope and degree of possible limitations imposed by European countries ${ }^{78}$.

\section{THE PERMISSIBILITY OF LIMITING RIGHTS AND FREEDOMS DUE TO THE NEED TO PROTECT HEALTH IN THE ECTHR JURISPRUDENCE}

As has been demonstrated so far, the content of the provisions of Articles 8-11 of the ECHR and Article 2 of the Additional Protocol No. 4 of the ECHR regarding the scope and degree of limitation is not uniform, as is also pointed out by the Strasbourg Court in its rulings ${ }^{79}$. As a result, in practice, states may interpret these provisions improperly and, consequently, violate human rights and freedoms owing to the need to protect human health and public morals. In practice, such cases are becoming more common. This obliges the ECtHR to adopt a more 'dynamic interpretation' of the provisions of Articles 8-11 of the ECHR and Article 2 of the Additional Protocol No. 4 of the ECHR and take account of the margin of appreciation that the states complained against may apply ${ }^{80}$. However, the action of a state is not always deliberate and conscious, hence the ECtHR must interpret these matters in concreto. The analysis of the number of cases shows that the court most often formally analysed relationships between health and the right to privacy and family life.

78 See: Robert Tabaszewski, "Health as a Value in the Integration Policy of European and East Asian Countries. Historical and Legal Perspective," Journal of European Integration History vol. 25, No. 1(2019): 106. To the extent that the CFR contains rights that correspond to the rights guaranteed in the ECHR, the meaning and scope of these rights are the same as the meaning and scope of the rights conferred by the Convention, which means that the powers of both courts overlap.

79 Berend Hovius, "The Limitation Clauses of The European Convention on Human Rights: A Guide for the Application of Section 1 of The Charter?," Yearbook of European Law vol. 6, No. 1(1986): 1-54.

80 Tadeusz Jasudowicz, Administracja wobec praw cztowieka, 31-32; See: Susan Marks, "The European Convention on Human Rights and its „democratic society, The British Yearbook of International Law No. 16(1995): 209-238. 
Complaints lodged by complainants against the national authorities that broke the limitation procedure have appeared since the beginning of the ECtHR and the no longer functioning European Commission of $\mathrm{Hu}-$ man Rights. When examining cases concerning the abuse of the possibility of using the limitation instrument by national authorities, the ECtHR begins by analysing whether there has been a violation of national law and the ECHR provisions and determining whether state interference in rights and freedoms was justified due to the need to protect public health ${ }^{81}$. The ECtHR then examines whether there was a legal basis for the state's interference or the purpose of protection (in this case the protection of public health) for which the interference was made, and whether the limitation was necessary from a democratic society's point of view ${ }^{82}$.

When analysing the court's case law, the following trends should be pointed out. As an object of the ECtHR jurisprudence, health is not only a personal attribute, but also a good of special importance to society ${ }^{83}$. However, the court makes no distinction between an individual's health and public health. At present, it is sufficient to state a premise for health protection, conditioning the protection of an individual's personal rights per se. This most often concerns the right referred to in Article 8 of the ECHR, and to a lesser extent also in Article 9, Article 10 and Article 11 of the ECHR, as well as the freedom mentioned in Article 2 of the Additional Protocol No. 4. The court now gives national authorities a very wide margin of appreciation as to whether it is possible to limit other rights due to the need to protect human health. In practice, the margin of appreciation regarding the limitation of rights and freedoms is wide as it is not contrary to the general provisions of the Convention ${ }^{84}$.

As regards the right to respect for private and family life, contained in Article 8(2) of the ECHR, the court recognised that a certain margin

81 Elizabeth Palmer, "Protecting Socio-Economic Rights through the European Convention on Human Rights: Trends and Developments in the European Court of Human Rights," Erasmus Law Review No. 4(2009):398.

82 B. Latos, Klauzula derogacyjna i limitacyjna w Europejskiej Konwencji o ochronie praw cztowieka i podstawowych wolności, 150-151.

83 Ibidem, 198; Steven Greer, "The exceptions to Articles 8 to 11 of the European Convention on Human Rights," Human Rights Files No. 15(1997): 24-29.

84 ECtHR, Case Jalloh v. Germany, application no. 54810/00. 
was left to national authorities regarding discretion as to whether a given human behaviour regarding their private and family life is compatible with the prerequisite for health protection. Therefore, health remains one of the main prerequisites allowing a state to interfere in the sphere of parental rights. An analysis of the Strasbourg Court's rulings shows that national authorities have extremely high powers regarding the possibility of restricting and depriving parental rights. This applies particularly to situations where a child's health and development are at risk. Limiting the right to privacy is therefore necessary because all parental negligence has implications for a child's physical and mental health as well as for their 'satisfactory care and education'85. With a view to a child's health, when deciding on the permissibility of a parent's contact with their child, it becomes possible to determine such permissibility on the basis of precisely defined statutory pre-conditions. Based on this, 'its scope and manner of implementation must be clearly defined to grant such protection against arbitrary interference' and the primacy of children's rights over the rights contained in the ECHR ${ }^{86}$.

In certain situations, the court has recognised that national authorities may abuse their right to limit private life as some provisions of family law may constitute an interference with the sphere of respect for the right of parents to raise children in accordance with their beliefs. The application of limitations allows a state to protect the rights and freedoms of others, in this case children, who should be protected in a special way so that state authorities can ensure their universal security ${ }^{87}$. It is different, however, when human behaviour is reduced only to interfering in one's own health, and the intensity of these actions can threaten the life of that person, even if their action or omission is consistent with the maxim volenti non fit

85 The permissibility of interference with parental powers on the grounds of health protection is justified by Polish legislation, which 'clearly aims to protect children and there is No. indication that this right was used in the present case for any other purpose'. ECtHR, Case Olsson v. Sweden, application no. 10465/83; ECtHR, Case Nielsen v. Denmark, application no. $10929 / 84$.

86 Donna Gomien, David John Harris, Leo Zwaak, Law and practice of the European Convention on Human Rights and the European Social Charter (Strasbourg: Council of Europe, 1996), 252. ECtHR, Case Eriksson v. Sweden, application no. 11373/85.

87 See: Handbook on European law relating to the rights of the child (Luxembourg: Council of Europe 2015). 
iniuria. This applies in particular to cases in which the complainant was unable to make deliberate decisions threatening their health.

In the light of the theory of limitations, although national authorities have a certain margin of discretion in this respect, they are obliged to counteract masochistic behaviour which has a negative impact on the undisturbed exercise of the rights and freedoms of other people. In the case of Laskey, Jaggard and Brown v. The United Kingdom ${ }^{88}$, the court recognised that the state was required to respond properly and adequately by protecting public health and morals even if that protection concerned such an intimate and personal sphere of life as the sphere of sexual health ${ }^{89}$. Undoubtedly, authorities also have an absolute obligation to respond to the existence of torture, regardless of whether it was carried out by mutual consent of all participants. This poses a threat not only to an individual, but to the health of the entire population ${ }^{90}$.

When examining the cases referred by complainants alleging violation of Article 9, Article 10 and Article 11 of the ECHR, as it did in the case of the right to respect for private and family life, the court recognised that these rights are not absolute and may be subject to limitation in the event of a threat to the protected good which is health ${ }^{91}$. State interference, within the margin of discretion, which is based on the prerequisite for the protection of health and morals, must be purposeful, justified, and 'necessary in a democratic society', that is, meet the requirements of sub-

88 ECtHR, Case Laskey, Jaggard $i$ Brown v. The United Kingdom, application no. $21627 / 93$.

89 ECtHR, Case Dudgeon v. The United Kingdom, application no. 7525/76; ECtHR, Case Norris v. Irland, application no. No. 10581/83; ECtHR, Case Modinos v. Cyprus, application no. No. 15070/89.

90 The premise to protect health and morals was tacitly accepted by the ECtHR until the late 1980 s in relation to the admissibility of criminalizing homosexual behavior. Masochistic behaviour should be qualified as justifying state interference, particularly when the behaviour performed by an individual goes beyond their sphere of privacy due to the level of suffering. In such a situation, it can be said that the prosecution and conviction of complainants were necessary in a democratic society for the protection of health within the meaning of Article 8(2) of the ECHR. Jarosław Krzysztof Warylewski, "Karalność praktyk sadomasochistycznych a prawo do prywatności," Gdańskie Studia Prawnicze No. 1(1999): 53-82.

91 ECtHR, Case Douglas-Williamsv. The United Kingdom, application no. No. 56413/00. 
stantive legality. For the sake of protecting the health of an individual and society, interference with freedom of thought, conscience and religion is permitted. These interventions may be permissible when 'health protection considerations, including hygiene of food production, or other values deserving protection, are involved ${ }^{92}$. In the case of Cisse $v$. France regarding the permissibility of the dissolution of a legal assembly for health reasons, the court considered that it was possible to dissolve a hunger strike in which persons were grouped in a place whose basic hygiene conditions could endanger all participants in the assembly ${ }^{93}$. Therefore, the premises that limiting strike activity or participation in specific religious ceremonies are real factors that are negative for health and threaten the population, especially when the assembly takes place in public buildings ${ }^{94}$.

The prerequisite for health protection, as the basis for limitation, also appeared in the context of a potential violation of Article 10 of the ECHR on freedom of expression, including about the functioning of the system of services operating in public health care ${ }^{95}$. In turn, the possibility of limiting the publication of opinions on a given product intended for marketing and its impact on human health became the subject of a ruling in the case of Hertel $v$. Switzerland. The applicant published his research in the local press. He reported that food prepared in microwave ovens is a danger to health and leads to changes in the blood of those who consume it. The article was illustrated with a photograph of a deadly reaper. He was convicted of this by local courts. According to the ECtHR, in this type of cases public health is at stake, so the margin of appreciation was limited to 'statements related to products on the market which were not purely "commercial" if these statements were expressed in a serious public debate,

92 ECtHR, Case Cha're Shalom Ve Tsedek v. France, application no. 27417/95; ECtHR, Case Vergos v. Greece, application no. 65501/01.

93 ECtHR, Case Cisse v. France, application no. 51346/99.

94 ECtHR, Case Tymoshenko et al. v. Ukraine, application no. 48408/12; ECtHR, Case Magyar Keresztény Mennonita Egyház et al., applications no. 70945/11, 23611/12, 26998/12, 41150/12, 41155/12, 41463/12, 41553/12, 54977/12 i 56581/12; ECtHR, Case Izci v. Turkey, application no. 42606/05.

95 See: ECtHR, Case Bergens Tidende et at. v. Norway, application no. 26132/95; ECtHR, Case Juppala v. Finland, application no. 18620/03; ECtHR, Case Frankowicz v. Poland, application no. 53025/99. 
including on health care ${ }^{96}$. Due to the prerequisite for health protection, it becomes possible to introduce actual limitations in advertising, including with respect to the promotion of certain types of pharmaceuticals and parapharmaceuticals, stimulants, psychotropic substances, drugs and other substances harmful to human health ${ }^{97}$. Most often, however, the prerequisite for protecting universal health in the limitation procedure is used by states in relation to so-called hard drugs, psychotropic substances and other types of stimulants.

The ECtHR made interesting considerations in the case of Palusinski $v$. Poland, dealing with the issue of the permissibility of restricting freedom of expression due to the obligation to protect life and health ${ }^{98}$. In 1996, the complainant was convicted for writing and publishing a book in which he examined marijuana, LSD and hallucinogenic mushrooms in detail, calling them 'soft drugs. The ECtHR concluded that the state did not violate Article 10 of the ECHR and met the goals of limitation. The monograph written by the complainant posed a threat to public health and provided very little information on the negative effects of the use of these substances and possible addiction to them ${ }^{99}$. Moreover, it posed a very serious threat to the health of the entire population because it contained 'instructions for obtaining ingredients and preparation' of drugs and 'doses to be taken'. The limitation of freedom of expression was justified in order to protect life and health. Hence, the court found that the Polish domestic courts had correctly applied the standards contained in Article 10 of the Convention and the authorities had provided 'relevant and sufficient' reasons for issuing their decisions in the field of protecting human health.

96 On the other hand, the ECtHR gives special protection to the possibility of referring to statements having a special, public character, including those related to public health. See: ECtHR, Case Hertel v. Switzerland application no. 25181/94.

97 ECtHR, Case Hachette Filipacchi Presse Automobile and Dupuy v. France, application no. $13353 / 05$.

98 See: ECtHR, Case Palusinski v. Poland, application no. 62414/00, LEX No. 195832.

99 See: Robert Palusinski, Narkotyki-przewodnik. Soft-Drugs: Marijuana, LSD-25, grzyby: historia, produkcja, sposób użycia, efekty, niebezpieczeństwa (Warszawa: Total Trade \& Publishers, 1994). 


\section{HEALTH AS A PREREQUISITE FOR LIMITING HUMAN RIGHTS AND FREEDOMS IN THE NATIONAL SYSTEM}

In the system of domestic law, just like in the European system, constitutional rights and freedoms related to the need to protect human life and health are not absolute. Restrictions applied due to the need to protect human health may result from norms of constitutional or conventional $\operatorname{rank}^{100}$. It should be noted that the current regulation of constitutional rank differs from the content of the European Convention on Human Right (ECHR), in which the possibility of restricting rights and freedoms other than the right to health due to the premise of 'health' is much broader. The Polish Constitution allows limiting certain rights and freedoms due to 'public health', that is the health of entire communities, not the health of an individual or the health of a group of people. Referring to the premise of 'public health protection' will justify interfering with other rights and freedoms if it is used to protect the existential interests of a very large number of members of society, and not individual people. It is worth noting here that the premise of 'public health protection' has nothing to do with the 'right to health protection' contained in article 68 of the Polish Constitution $^{101}$. The law formulated therein has the character of a norm guaranteeing all citizens access to health protection measures, particularly to health care services.

According to the Polish Constitutional Tribunal, 'the first reason for which all individual rights can be limited is the protection of the common good', primarily regarding the need to ensure personal and individual se-

${ }^{100}$ Robert Tabaszewski, Prawo do zdrowia, 163-165.

101 See: art. 68 of The Constitution of the Republic of Poland: "(1) Everyone shall have the right to have his health protected. (2) Equal access to health care services, financed from public funds, shall be ensured by public authorities to citizens, irrespective of their material situation. The conditions for, and scope of, the provision of services shall be established by statute. (3) Public authorities shall ensure special health care to children, pregnant women, handicapped people and persons of advanced age. (4) Public authorities shall combat epidemic illnesses and prevent the negative health consequences of degradation of the environment. (5) Public authorities shall support the development of physical culture, particularly amongst children and young persons. 
curity, pursuant to the provision in Article 5 of the Polish Constitution ${ }^{102}$. Secondly, in order to protect life and health, the Constitutional Tribunal has decided that it is possible to deprive citizens of not only economic, social and cultural rights, which constitute the so-called second generation of human rights, but also of the rights of the first generation. It is therefore possible to deprive citizens of personal rights and freedoms regarding an individual's private life, including their fundamental rights, when it is necessary to protect human health, if this does not lead to a violation of human dignity. This is due to the need to protect human life and health, which is an extension of the constitutional principle of a democratic state of law ${ }^{103}$. According to the Constitutional Tribunal, 'constitutional guarantees for the protection of human life must therefore necessarily include health protection'; the provisions constituting the basis of these guarantees therefore also constitute the basis for inferring a constitutional obligation to protect health, regardless of the degree of physical, emotional, intellectual or social development ${ }^{104}$.

Health, along with life, is treated in the Constitution as a superior good. This makes it possible to consider health a subjective right because it is 'simple emanation of dignity' ${ }^{105}$. Unlike ECHR regulations, the Polish system puts more emphasis on the compatibility of rights and freedoms related to human health with the attribute of dignity. The Constitution assumes that since the right to health is essentially connected and normatively associated with dignity, and, as a rule, it is to serve this dignity, this right

102 See: art. 5 of The Constitution of the Republic of Poland: "The Republic of Poland shall safeguard the independence and integrity of its territory and ensure the freedoms and rights of persons and citizens, the security of the citizens, safeguard the national heritage and shall ensure the protection of the natural environment pursuant to the principles of sustainable development".

${ }^{103}$ Polish Constitutional Tribunal, Judgment of $4^{\text {th }}$ November 2006, sign. K 19/06 Journal of Laws 2010, No. 215, item 1418, as amended; Polish Constitutional Tribunal, Judgment of $23^{\text {rd }}$ June 2009, sign. K 54/07, Journal of Laws 2009, No. 105, item 880, as amended.

${ }_{104}$ Polish Constitutional Tribunal, Judgment of $28^{\text {th }}$ May 1997, sign. K 26/96, Journal of Laws 1999, No. 102, item 643, as amended.

105 Andrzej Zoll, "Problemy stużby zdrowia w świetle doświadczeń RPO," Prawo i Medycyna No. 8(2000): 8; Michał Piechota, "Konstytucyjne prawo do ochrony zdrowia jako prawo socjalne i prawo podstawowe," Roczniki Administracji i Prawa, No.12(2012): 93. 
cannot be subject to restrictions other than constitutional. The exception is one of the social components of this right, that is, the right to healthcare, the content and scope of which is subject to statutory modifications ${ }^{106}$. In the light of the Constitution, man can dispose of their freedom, including a free choice in the scope of disposing of their health status, which leaves them with a free choice of all factors influencing health ${ }^{107}$. The limits of this activity are only determined by the maxim quod non vetat lex, hoc vetat fieri pudor108.

The possibilities of limiting other rights and freedoms due to the premise of 'public health and morality protection' are provided for in provisions of the constitutional and statutory rank ${ }^{109}$. In particular, this possibility has been provided for in Article 31.3 of the Constitution. According to the Constitutional Tribunal, this 'possibility for the legislator of limiting the scope of exercising freedom due to health protection may refer to the protection of health of the entire society or individual groups, as well as the health of particular persons ${ }^{110}$. The development of this norm enables appropriate measures to be taken by the relevant organs of the state apparatus, in particular by means of administrative measures ${ }^{111}$. The need to respect human health in a democratic society as a value listed in Article 31.3 of the Constitution, in addition to goods such as: state security, public order, the environment, and freedoms and rights of other persons, does not justify depriving an individual of the right to assert their freedoms and rights in the court, as

106 Robert Tabaszewski, Prawo do zdrowia, 170-171.

107 See: article 32.1 of the Constitution of the Republic of Poland.

${ }^{108}$ John R. Stone, Routledge Dictionary of Latin Quotations: The Illiterati's Guide to Latin Maxims, Mottoes, Proverbs, and Sayings (New York: Routledge, 2005), 102.

${ }_{109}$ Robert Tabaszewski, Prawo do zdrowia, 171-172.

${ }^{110}$ Polish Constitutional Tribunal, Judgment of $9^{\text {th }}$ July 2009, sign. SK 48/05 Journal of Laws 2009, No. 114, item 956.

${ }^{111}$ Polish Constitutional Tribunal, Judgment of $18^{\text {th }}$ July 2011, sign. K 25/09 Journal of Laws 2011, No. 156, item 934; Polish Constitutional Tribunal, Judgment of $12^{\text {th }}$ November 2002, sign. SK 40/01 Journal of Laws 2002, No. 194, item 1641; Polish Constitutional Tribunal, Judgment of $11^{\text {th }}$ October 2006, sign. P3/06 Journal of Laws 2006, No. 190, item 1409. 
assumed in Article 77.2 of the Constitution, which enables the use of the institution of a constitutional complaint ${ }^{112}$.

Possible restrictions of human rights and freedoms due to the premise of human health are also provided for in the provisions of the Constitution of 1997 on emergency states. In accordance with the Chapter XI of the Constitution, an appropriate state of emergency may be introduced in situations of particular threats, if ordinary constitutional measures are insufficient, and there is a condition requiring emergency measures, including to protect human life and health ${ }^{113}$. In order to protect human health and life, among others, a state of natural disaster is introduced, which means 'natural disaster or technical failure, the effects of which threaten the life or health of a large number of people, property of large sizes or the environment in large areas'. In such a situation, 'assistance and protection can be effectively provided only with extraordinary measures, in cooperation of various bodies and institutions, as well as specialist services and formations operating under a single management' ${ }^{114}$.

In the event of martial law or a state of emergency, it is not possible to introduce the restrictions enumerated in Article 233.1, including on the protection of life ${ }^{115}$ and personal rights (Article 47), that is, the components of the right to health according to the World Health Organization $(\mathrm{WHO})^{116}$. However, the list of underogated rights does not include the provision of Article 68 of the Constitution, which means that in emergency situations it is possible to limit the benefits and other rights of an individual arising from the universal health care system. During martial law, it is possible to limit human freedoms and rights, and to impose additional obligations on individuals, but only to the extent that their personal and family conditions, including their health, allow. In no case, however, is it possible to limit the rights and freedoms of individuals exposing them to

112 Marek Szydło, “Komentarz do art. 31," in Konstytucja RP, t. I: Komentarz do art. 1-86, ed. Marek Safjan, Leszek Bosek (Warszawa: C.H. Beck, 2016).

113 See: article 228.1 of the Constitution of the Republic of Poland.

${ }_{114}$ Robert Tabaszewski, Prawo do zdrowia, 171-172.

115 See: article 38 of the Constitution of the Republic of Poland.

116 Frank Grad, "The Preamble of the Constitution of the World Health Organisation," Bulletin of the World Health Organisation 12(2002): 981-984. 
health and life threats expressly, and the behaviour of public officials who pose a direct threat to the life or health of civilians is unacceptable ${ }^{117}$.

While the abovementioned restrictions due to the premise of an individual's health protection are addressed to public authorities, the subject of subsequent constitutional restrictions are entities whose activities could potentially affect the health of other people ${ }^{118}$. The Constitution provides for three situations in which health is superior to other goods. The first concerns Article 53.5, enabling statutory restrictions on the freedom to manifest religion when it is necessary to protect state security, public order, health, morality or the freedom and rights of others. The second group of restrictions resulting from the obligation to comply with the legal conditions for conducting business activity has been included in Article 76 of the Constitution ${ }^{119}$. Entrepreneurs as qualified entities have been obliged to comply with specific requirements regarding protection against threats to human life and health, as well as other conditions set out in building, sanitary, fire and environmental protection regulations ${ }^{120}$.

The second constitutional exception, which allows limitation of the constitutional right to health, is established by the Constitution in the provision of Article 68.2. The provision introduces the possibility of actually limiting the component of the right to health protection, resulting from the specific structure of the provision itself, which states that 'the terms of healthcare services shall be specified by statute', which leaves the legislator too much freedom, including the possibility of introducing additional fees for basic medical services. An overly restrictive interpretation of this provision may consequently be seen as an opportunity to limit access to healthcare.

117 Act on state of emergency of $21^{\text {th }}$ June 2002, Journal of Laws 2014, No. 111, as amended.

${ }^{118}$ Polish Constitutional Tribunal, Judgment of $9^{\text {th }}$ July 2009, sign. SK 48/05 Journal of Laws 2009, No. 114, item 956.

${ }^{119}$ See: Robert Tabaszewski, "Dopuszczalne ograniczenia prawa podejmowania i prowadzenia działalności zawodowej lub gospodarczej ze względu na przesłankę ochrony zdrowia," in Ochrona praw cztowieka w Polsce. Aksjologia - instytucje - nowe wyzwania praktyka, ed. Jerzy Jaskiernia, Kamil Spryszak (Toruń: Adam Marszałek, 2017), 115-135.

120 Supreme Administrative Court, Judgment of $14^{\text {th }}$ March 2006 r., OSK Pos. 67(2006 r.); See: Krzysztof Walczak, "Corporate governance - moda czy konieczność," Monitor Prawa Pracy nr 9(2005). 
Such a limitation of the right to health protection is first of all possible when state resources do not allow it to be fully shaped in a democratic state in accordance with the principle of equality ${ }^{121}$. In this context, attention should be paid to the functioning on the medical market of entities (e.g. doctors, nurses, midwives and paramedics) whose business is health. The Constitutional Tribunal has decided that their activity requires special qualifications and the quality of their services cannot be limited ${ }^{122}$.

The last group of constitutional restrictions on the rights and freedoms due to the primacy of human health is provided for by the electoral law. The Constitutional Tribunal states that, like other rights and freedoms, electoral rights are not absolute, which means that they can be limited due to the need to protect public health. The Constitution provides for only two possible exceptions to the full exercise of active and passive voting rights, aimed at protecting human health ${ }^{123}$. With regard to individual health, procedural restrictions for individuals are contained in the Constitution $^{124}$. On the other hand, the public health norm which has been included in Article 31.3 of the Constitution is more general. It allows limiting the use of the constitutional electoral law by 'everyone'. Much more detailed regulations limiting electoral rights due to human health protection are provided for by the Electoral Code.

\section{FINAL REMARKS}

The above analysis of the most important European and national domestic regulations has shown that health is a prerequisite for limiting the so-called absolute rights. Actually, the protection of health is the most valuable constitutional value in the domestic human rights protection sys-

121 Robert Tabaszewski, Prawo do zdrowia, 171-173.

122 Polish Constitutional Tribunal, Judgment of $23^{\text {th }}$ April 2008, sign. SK 16/07.

123 See: Robert Tabaszewski, "Dopuszczalność ograniczania czynnego i biernego prawa wyborczego ze względu na potrzebę ochrony zdrowia," in 25 lat demokratycznego prawa wyborczego i organów wyborczych w Polsce (1991-2016). Ksiega jubileuszowa, t. II, eds. Wojciech Hermeliński, Beta Tokaj (Warszawa: Państwowa Komisja Wyborcza, Krajowe Biuro Wyborcze, 2016), 75-84.

${ }^{124}$ See: Article 62.2 of the Constitution of the Republic of Poland. 
tem. Most often it appears as a dependent prerequisite together with the obligation to protect morals and the need to ensure national security ${ }^{125}$. Importantly, in recent years, Strasbourg judges have increasingly emphasised the need to limit social rights and freedoms due to the requirement to protect health. This is a consequence of the court's adoption of the concept of a holistic interpretation of the provisions of the Convention, requiring a holistic analysis of the legally binding documents of the $\mathrm{CoE}$, which include guarantees regarding human rights and freedoms. The health protection order, supported by ECtHR and Strasbourg case law, obliging national authorities to take all necessary steps for a fuller implementation of this right, even at the cost of limiting other rights and freedoms, also appears in national constitutions, codes and other documents regarding personal rights and the security of an individual ${ }^{126}$.

In addition to the ECHR, the possibility of limitation is provided for in a number of $\mathrm{CoE}$ conventions in the field of personal security of an individual, which, however, have not been ratified by Poland and do not constitute a formal source of rights and freedoms for persons staying in the territory of the Republic of Poland. In this group of documents, Article 26 of the Convention on Human Rights and Biomedicine (Oviedo Convention) should be considered the most important ${ }^{127}$. The provisions contained therein allow the formulation of the conclusion that, in principle, the rights and freedoms protected in the European system and, consequently, the rights and freedoms protection systems of member states are not absolute. This means that in the event of a threat to human health in the universal dimension, they are subject to the mecha-

125 See: Marta Szuniewicz, Ochrona bezpieczeństwa państwa jako przestanka ograniczenia praw i wolności jednostki w świetle Europejskiej Konwencji Praw Cztowieka (Warszawa: C.H. Beck, 2016).

126 See: David Beyleveld, Roger Brownsword, Human dignity in bioethics and biolaw (Oxford: Oxford University Press 2001), 29-47.

127 This provision introduces limitations on the exercise of rights and guarantees for an individual that 'are prescribed by law and are necessary in a democratic society in the interest of public safety, for the prevention of crime, for the protection of public health or for the protection of the rights and freedoms of others'. See: Council of Europe, Convention for the Protection of the Human Being with regard to the Application of Biology and Medicine: Convention on Human rights and Biomedicine, Oviedo, 4 April 1997, ETS No. 164. 
nism of actual limitation. Moreover, the possibility of specific limitation of rights and freedoms has been increasingly provided for in many resolutions of the statutory bodies of regional organisations, often inspired by the ECtHR jurisprudence. All this confirms that health is universally considered a good of special importance for society by national authorities, who, however, must take into account that the effect of the limitation will be examined and evaluated by the ECtHR.

Unfortunately, due to the SARS-COV-2 pandemic, legal solutions used so far have not stood the test of time. From early 2020, as many as 46 out of 47 member states of the Council of Europe have decided to temporarily limit civil rights and freedoms ${ }^{128}$. The governments of these countries have considered it expedient to introduce additional legal restrictions due to the unprecedented nature and extent of the threat to human health and life and public security. Public authorities declare that these temporary restrictions of rights and freedoms have been introduced solely to protect human health. This position has also been adopted by the Strasbourg Court, which has considered SARS-COV-2 to be the most dangerous epidemic since World War II and has thus decided to limit the current mode of work and extend the deadlines for submitting complaints $^{129}$. Starting from 16 March 2020, due to potential threats to universal health, the procedure for asserting rights and freedoms in the Court has also been modified.

In response to the unprecedented global health crisis, Polish authorities have also decided that there is a need to protect health on a universal scale, even at the cost of limiting fundamental rights and freedoms. Admittedly, the provision of Article 230 of the Constitution, enabling the introduction of a state of emergency, has not been used, but the provisions of the Act of 5 December 2008 on preventing and combating infections

${ }^{128}$ Marija Pejčinović Burić, Respecting democracy, rule of law and human rights in the framework of the COVID-19 sanitary crisis. A toolkit for member states (Strasbourg: Council of Europe, 2020).

${ }_{129}$ See: Alessandra Pierucci, Jean-Philippe Walter, Joint Statement on the right to data protection in the context of the COVID-19 (Strasbourg: Council of Europe, 2020); DH-Bio, DH-BIO Statement on human rights considerations relevant to the COVID-19 pandemic (Strasbourg: Council of Europe, 2020). 
and infectious diseases in humans have been applied ${ }^{130}$. Thus, under the ordinance of the Minister of Health of 20 March 2020, an epidemic was announced in the territory of the Republic of Poland ${ }^{131}$. The regulations introduced in Poland in March and April 2020 make it possible to limit the vast majority of rights and freedoms on an unprecedented legal scale due to the need to preserve human health. In particular, freedom of movement, freedom of economic activity, right of access to court and freedom of religious practice have been radically limited.

The steps taken by the Polish authorities and the governments of individual member states of the European Union confirm the thesis contained in the article about the primacy of public health over other rights and freedoms. The practice of the states to date indicates that limitation of rights and freedoms due to the need to protect public health is not only possible and desirable, but can be the only way to preserve human life and health security of its citizens in crisis situations, provided that it is carried out after careful assessment of the situation and that it complies with the law.

\section{REFERENCES}

\section{Literature}

Roscam Abbing, Henriette. "Health Law \& the European Union". European Journal of Health Law 1994, No. 1: 123-126.

Anđelković, Luka. "The elements of proportionality as a principle of human rights limitations". Facta Universitatis Series: Law and Politics 15, No. 3(2017): 235-244.

Arai-Takahashi, Yutaka. The Margin of Appreciation Doctrine and the Principle of Proportionality in the Jurisprudence of the ECtHR. Antwerpen-Oxford-New York: Intersentia, 2001.

Banaszak, Bogusław. System ochrony praw człowieka. Kraków: Wolters Kluwer, 2003. Benvenisti, Eyal. "Margin of appreciation, consensus, and universal standards". The New York University Journal of International Law and Politics No. 31(1999): 843-854.

${ }^{130}$ Journal of Laws 2009, No. 234, item 1570, as amended.

131 Journal of Laws 2020, item 491, as amended. 
Beyleveld, David, Brownsword, Roger. Human dignity in bioethics and biolaw. Oxford: Oxford University Press 2001.

Blaxter, Mildred. Zdrowie. Warszawa: Wydawnictwo Sic!, 2009.

Charles, John. "Origins, history, and achievements of the World Health Organization". The British Medical Journal vol. 4, No. 2(1968), 293-296.

Connelly, Adeline M. "Problems of Interpretation of Article 8 of the European Convention on Human Rights". International \& Comparative Law Quarterly vol. 35, No. 3(1986): 567-593.

Croquet, Nicolas. The Role and Extent of a Proportionality Analysis in the Judicial Assessment of Human Rights Limitations within International Criminal Proceedings. Leiden: Brill-Nijhoff, 2015. 286.

DH-Bio. DH-BIO Statement on human rights considerations relevant to the COVID-19 pandemic. Strasbourg: Council of Europe, 2020.

Gomien, Donna, Harris, David, John, Zwaak, Leo, Law and practice of the European Convention on Human Rights and the European Social Charter. Strasbourg: Council of Europe, 1996.

Górski, Łukasz. "Prawa jednostki wobec praw grupy. Konflikt czy współistnienie?” In Cztowiek - jego prawa i odpowiedzialność, edited by Robert Tabaszewski, 27-29. Lublin: KUL, 2013.

Grad, Frank. "The Preamble of the Constitution of the World Health Organisation". Bulletin of the World Health Organisation 12(2002): 981-984.

Grant, John, Barker, Craig. Encyclopedic Dictionary of International Law. Oxford: Oxford University Press, 2009.

Greer, Steven. "The exceptions to Articles 8 to 11 of the European Convention on Human Rights". Human Rights Files No. 15(1997): 24-29.

Gross, Oren, Ní Aoláin, Fionnuala. "From Discretion to Scrutiny: Revisiting the Application of the Margin of Appreciation Doctrine in the Context of Article 15 of the European Convention on Human Rights". In Human Rights Quarterly No. 3(2001):625-649.

Habibi, Roojin Dagron, Stephanie Gostin, Lawrence O. Negri, Stefania et al. "Do not violate the International Health Regulations during the COVID-19 outbreak". Lancet 29;395(2020): 664-666.

Handbook on European law relating to the rights of the child. Luxembourg: Council of Europe 2015.

Hannum, Hurst. "The UDHR in National and International Law". Health and Human Rights 3, No. 2(1998): 147.

Hovius, Berend. "The Limitation Clauses of The European Convention on Human Rights: A Guide for the Application of Section 1 of The Charter?”. Yearbook of European Law vol. 6, No. 1(1986): 1-54. 
Jasudowicz, Tadeusz. "Granice wymagalności międzynarodowo chronionych praw człowieka," In Prawa cztowieka $i$ ich ochrona, edited by Bożena Gronowska, 227-235. Toruń: TNOiK, 2010.

Jasudowicz, Tadeusz. "Limits of Enjoyment of Human Rights in the System of the European Social Charter". Polish Review of International and European Law vol. 6, No. 1(2017): 49-70.

Jasudowicz, Tadeusz. Administracja wobec praw cztowieka. Toruń: TNOiK 1996. Kapelańska-Pręgowska, Julia. "Koncepcja tzw. marginesu oceny w orzecznictwie Europejskiego Trybunału Praw Czowieka”. Państwo i Prawo No. 12, 2007: 88. Kiedik, Dorota, Fal, Andrzej. "Zdrowie jednostki." In Zdrowie publiczne. Podręcznik akademicki, edited by Anna Felińczak, Adam Fal, 9. Wrocław: Akademia Medyczna im. Piastów Śląskich, 2010.

Kratochvíl, Jan. "The inflation of the margin of appreciation by the European Court of Human Rights". Netherlands Quarterly of Human Rights No. 3(2011): 326-328.

Krennerich, Michael. "The Human Right to Health Fundamentals of a Complex Right". In Healthcare as a Human Rights Issue. Normative Profile, Conflicts and Implementation, edited by Sabine Klotz, Heiner Bifeldt, Martina Schmidhuber, Andreas Frewer. Bielefeld: Verlag, 2017.

Kuczma, Paweł. Prawa cztowieka w zarysie. Polkowice: Dolnośląska Wyższa Szkoła Przedsiębiorczości i Techniki, 2011.

Łabno, Anna. "O ograniczenie wolności i praw człowieka na podstawie art. 31 Konstytucji III RP”. In Prawa i wolności obywatelskie w Konstytucji RP, edited by Bogusław Banaszak, Artur Preisner, 693-694. Warszawa: C.H. Beck, 2002. Latos, Bartłomiej. Klauzula derogacyjna $i$ limitacyjna $w$ Europejskiej Konwencji o ochronie praw cztowieka i podstawowych wolności. Warszawa: Wydawnictwo Sejmowe, 2008.

Malhotra, Varun M. "Freedom of expression and health: is the association causal?", Lancet vol. 38 (2016): 561.

Marks, Susan. "The European Convention on Human Rights and its „democratic society”. The British Yearbook of International Law No. 16(1995): 209-238.

Mizerski, Rafał. "Granice wymagalności międzynarodowo chronionych praw człowieka”. In Prawa cztowieka i ich ochrona, edited by Bożena Gronowska, 234-235. Toruń: TNOiK, 2010.

Morawska, Elżbieta. "Prawa konstytucyjne człowieka i obywatela w Rzeczypospolitej Polskiej a prawa podstawowe Unii Europejskiej. Analiza porównawcza”. Przeglad Sejmowy No. 1(2009): 41.

Murphy, Theresa. Health and Human Rights. Oxford-Portland-Oregon: Hart Publishing, 2013. 
Nowicki, Marek, Antoni. Stownik Europejskiej Konwencji Praw Cztowieka. Warszawa: Wolters Kluwer Polska, 2009.

Opolski, Janusz, Miller, Maria. "Marcin Kasprzak. Komentarz do prac". Postępy Nauk Medycznych 2009, No. 4: 317-318.

Palmer, Elizabeth. "Protecting Socio-Economic Rights through the European Convention on Human Rights: Trends and Developments in the European Court of Human Rights". Erasmus Law Review No. 4(2009): 398.

Palusinski, Robert. Narkotyki-przewodnik. Soft-Drugs: Marijuana, LSD-25, grzyby: historia, produkcja, sposób użycia, efekty, niebezpieczeństwa. Warszawa: Total Trade \& Publishers, 1994.

Parsons, Talcott. Struktura spoteczna a osobowość. Państwowe Wydawnictwo Ekonomiczne: Warszawa, 1969.

Peers, Steve. "Taking Rights Away? Limitations and Derogations". In The European Union Charter of Fundamental Rights, edited by Steve Peers, Angela Ward, 143-148. Oxford-Portland-Oregon: Hart Publishing, 2004.

Pejčinović Burić, Marija. Respecting democracy, rule of law and human rights in the framework of the COVID-19 sanitary crisis. A toolkit for member states. Strasbourg: Council of Europe, 2020.

Piechota, Michał. "Konstytucyjne prawo do ochrony zdrowia jako prawo socjalne i prawo podstawowe". Roczniki Administracji i Prawa, No. 12(2012): 93.

Piechowiak, Marek. "Klauzula limitacyjna a nienaruszalność praw i godności". Przeglad Sejmowy No. 2 (2009): 55-77.

Pierucci, Alessandra. Walter Jean-Philippe, Joint Statement on the right to data protection in the context of the COVID-19. Strasbourg: Council of Europe, 2020.

Riedel, Eibe. "The Human Right to Health: Conceptual Foundations". In Realizing the Right to Health, edited by Andrew Clapham, Mary Robinson, 28. Zurich: Rüfe\&Rub, 2009.

Shany, Yuval. "Toward a General Margin of Appreciation Doctrine in International Law?”. European Journal of International Law No. 16(2005): 907-940.

Silva, Diego, Smith, Maxwell. "Limiting rights and freedoms in the context of Ebola and other public health emergencies: how the principle of reciprocity can enrich the application of the Siracusa Principles". Health and Human Rights Journal vol. 17, No. 1(2015): 52-57.

Stone, John R. Routledge Dictionary of Latin Quotations: The Illiterati's Guide to Latin Maxims, Mottoes, Proverbs, and Sayings. New York: Routledge, 2005.

Sutton, Victoria. "Emergencies, disasters, conflicts, and human rights". In Advancing the human right to health, edited by José M. Zuniga, Stephen P. Marks, Lawrence O. Gostin, 379-388. Oxford: Oxford University Press, 2013. 
Szuniewicz, Marta. Ochrona bezpieczeństwa państwa jako przestanka ograniczenia praw i wolności jednostki w świetle Europejskiej Konwencji Praw Człowieka. Warszawa: C.H. Beck, 2016.

Szydło, Marek. "Komentarz do art. 31". In Konstytucja RP, t. I: Komentarz do art. 1-86, edited by Marek Safjan, Leszek Bosek. Warszawa: C.H. Beck, 2016. Tabaszewski, Robert. "Achieving the Sustainable Development Goals in Europe and Asia: role of regional organizations in monitoring human right to health and well-being." Ius Novum Vol. 13, No. 2(2019): 250-269.

Tabaszewski, Robert. "Dopuszczalne ograniczenia prawa podejmowania i prowadzenia działalności zawodowej lub gospodarczej ze względu na przesłankę ochrony zdrowia”. In Ochrona praw cztowieka w Polsce. Aksjologia - instytucje - nowe wyzwania - praktyka, edited by Jerzy Jaskiernia, Kamil Spryszak, 115-135. Toruń: Adam Marszałek, 2017.

Tabaszewski, Robert. "Dopuszczalność ograniczania czynnego i biernego prawa wyborczego ze względu na potrzebę ochrony zdrowia". In 25 lat demokratycznego prawa wyborczego i organów wyborczych $w$ Polsce (1991-2016). Ksiega jubileuszowa, t. II, edited by Wojciech Hermeliński, Beta Tokaj, 75-84. Warszawa: Państwowa Komisja Wyborcza, Krajowe Biuro Wyborcze, 2016.

Tabaszewski, Robert. "Health as a Legal Term and its Evolution in the Council of Europe's Human Rights Protection System”. Studia Etckie No. 4(2019): 583-594.

Tabaszewski, Robert. "Health as a Value in the Integration Policy of European and East Asian Countries. Historical and Legal Perspective". Journal of European Integration History vol. 25, No. 1(2019): 106.

Tabaszewski, Robert. "Rola ius cogens i soft law Światowej Organizacji Zdrowia w kształtowaniu praw i wolności człowieka”. In Ius cogens - soft law, dwa bieguny Prawa Międzynarodowego Publicznego. Księga dedykowana profesorowi Uniwersytetu Jagiellońskiego Kazimierzowi Lankoszowi, edited by Milena Ingelevič-Citak, Brygida Kuźniak, 390-401. Kraków: Wydawnictwo Uniwersytetu Jagiellońskiego, Kraków, 2017.

Tabaszewski, Robert. Prawo do zdrowia w systemach ochrony praw cztowieka. Lublin: KUL, 2020.

Tobin, John. The Right to Health in International Law. Oxford: Oxford University Press, 2012.

Toebes, Brigit. The Right to Health as a Human Right in International Law. Antwerpen: Intersentia/Hart, 1999.

Triantafyllou, Dimitris "The European Charter of Fundamental Rights and the "Rule of Law": Restricting Fundamental Rights by Reference". Common Market Law Review No. 1(2002): 53. 
Walczak, Krzysztof. “Corporate governance - moda czy konieczność”. Monitor Prawa Pracy nr 9(2005).

Warylewski, Jarosław, Krzysztof. "Karalność praktyk sadomasochistycznych a prawo do prywatności”. Gdańskie Studia Prawnicze No. 1(1999): 53-82.

Wiśniewski, Adam. "Uwagi o zastosowaniu koncepcji marginesu oceny w prawie międzynarodowym". In Prawo międzynarodowe i wspólnotowe wobec wyzwań wspótczesnego świata, edited by Elżbieta Dynia, 330. Rzeszów: Wydawnictwo Uniwersytetu Rzeszowskiego, 2009.

Wiśniewski, Adam. "W sprawie koncepcji marginesu oceny w orzecznictwie strasburskim”. Państwo i Prawo No. 2(2008): 97-104.

Wiśniewski, Adam. Koncepcja marginesu oceny w orzecznictwie Europejskiego Trybunatu Praw Cztowieka. Gdańsk: Wydawnictwo Uniwersytetu Gdańskiego, 2008. Wojtyczek, Krzysztof. Granice ingerencji ustawodawczej $w$ sfere praw cztowieka w Konstytucji RP. Kraków: Zakamycze, 1999.

Zakolska, Joanna. "Problem klauzuli ograniczającej korzystanie z praw i wolności człowieka w pracach konstytucyjnych, w poglądach doktryny i orzecznictwa Trybunału Konstytucyjnego". Przeglad Sejmowy No. 5 (2005): 11-29.

Zimmermann, Jan. Prawo administracyjne. Kraków: Zakamycze, 2006.

Zoll, Andrzej. "Problemy służby zdrowia w świetle doświadczeń RPO". Prawo i Medycyna No. 8(2000): 8.

\section{Documents}

The Constitution of the Republic of Poland, Journal of Laws 1997, No 78, item 483, as amended.

Act on state of emergency of $21^{\text {th }}$ June 2002, Journal of Laws 2014, No. 111, as amended.

Act on preventing and combating infections and infectious diseases in humans of $5^{\text {th }}$ December 2008, Journal of Laws 2009, No. 234, item 1570, as amended.

Ordinance of the Minister of Health of $20^{\text {th }}$ March 2020Journal of Laws 2020, item 491, as amended.

Council of Europe, European Convention on Human Rights and Fundamental Freedoms, Rome, 4 November 1950 as amended by Protocols Nos. 11 and 14 supplemented by Protocols Nos. 1, 4, 6, 7, 12, 13 and 16, ETS No. 5: ETS No. 009, 4: ETS No. 046, 6: ETS No. 114, 7: ETS No. 117, 12: ETS No. 177.

Council of Europe, European Social Charter Turin, ETS No. 035, 10 October 1961. Council of Europe, European Social Charter: Conclusions XIV-2 - Articles 1, 2, 3, 4, 9, 10, 15 and Articles 1 to 4 of the 1988: Norway.

Council of Europe, Revised European Social Charter, as amended, ETS No. 163. Strasbourg, 3 May 1996. 
European Union: Charter of Fundamental Rights of the European Union. Official Journal of the European Communities, C 364, 18 December 2000.

Council of Europe, Convention for the Protection of the Human Being with regard to the Application of Biology and Medicine: Convention on Human rights and Biomedicine, Oviedo, 4 April 1997, ETS No. 164.

The Limburg Principles on the implementation of the International Covenant on Economic, Social and Cultural Rights, UN ESCOR, Commission on $\mathrm{Hu}-$ man Rights, Forty-third Sess, Agenda Item 8, UN Doc. E/CN.4/1987/17, Annex (1987).

UN Charter and Statute of the International Court of Justice, signed on 26 June 1945 at the San Francisco Conference.

UN, Convention on the Rights of the Child adopted and opened for signature, ratification and accession by General Assembly resolution 44/25 of 20, UN Doc. No. 27531 November 1989.

UN, Economic and Social Council, Siracusa Principles on the Limitation and Derogation Provisions in the International Covenant on Civil and Political Rights, 1984 Siracusa, Italy, U.N. Doc. E/CN.4/1985/4, Annex.

UN, Human Rights Committee, Case André Brun v. France. Communication No. 1453/2006, U.N. Doc. CCPR/C/88/D/1453/2006, Geneve 2006.

UN, International Covenant on Civil and Political Rights (ICCPR) (adopted 16 December 1966; entered into force 23 March 1976), UNTS 999: 171.

UN, International Covenant on Economic, Social and Cultural Rights (ICESCR) (adopted 16 December 1966; entered into force 3 January 1976), UNTS 993: 3.

UN, The Maastricht Guidelines on Violations of Economic, Social and Cultural Rights, UN Doc. E/C.12/2000/13(2000).

UN, Universal Declaration of Human Rights adopted 10 December 1948), G.A. Res. 217A (III), U.N. Doc. A/810 at 71 (1948).

UN, Vienna Convention on the Law of Treaties, May 23, 1969, Vienna, 1155 U.N.T.S. 331, 8 I.L.M. 679.

UN, Vienna Declaration and Programme of Action, A/CONF.157/23, 12 July 1993. Judgements

Polish Constitutional Tribunal, Judgment of $28^{\text {th }}$ May 1997, sign. K 26/96, Journal of Laws 1999, No. 102, item 643, as amended.

Polish Constitutional Tribunal, Judgment of $12^{\text {th }}$ January 2000, sign. P 11/98, Journal of Laws 2000, No 3, item 46, as amended.

Polish Constitutional Tribunal, Judgment of $12^{\text {th }}$ November 2002, sign. SK 40/01 Journal of Laws 2002, No. 194, item 1641. 
Polish Constitutional Tribunal, Judgment of $11^{\text {th }}$ October 2006, sign. P 3/06 Journal of Laws 2006, No. 190, item 1409.

Polish Constitutional Tribunal, Judgment of $4^{\text {th }}$ November 2006, sign. K 19/06 Journal of Laws 2010, No. 215, item 1418, as amended.

Polish Constitutional Tribunal, Judgment of $23^{\text {th }}$ April 2008, sign. SK 16/07.

Polish Constitutional Tribunal, Judgment of $9^{\text {th }}$ July 2009, sign. SK 48/05 Journal of Laws 2009, No. 114, item 956.

Polish Constitutional Tribunal, Judgment of $23^{\text {rd }}$ June 2009, sign. K 54/07, Journal of Laws 2009, No. 105, item 880, as amended.

Polish Constitutional Tribunal, Judgment of $18^{\text {th }}$ July 2011, sign. K 25/09 Journal of Laws 2011, No. 156, item 934.

Supreme Administrative Court, Judgment of $14^{\text {th }}$ March 2006 r., OSK Pos. 67(2006 r.). ECtHR, Case Bergens Tidende et at. v. Norway, application no. 26132/95.

ECtHR, Case Cha're Shalom Ve Tsedek v. France, application no. 27417/95.

ECtHR, Case Douglas-Williamsv. The United Kingdom, application no. No. 56413/00.

ECtHR, Case Dudgeon v. The United Kingdom, application no. 7525/76.

ECtHR, Case Eriksson v. Sweden, application no. 11373/85.

ECtHR, Case Frankowicz v. Poland, application no. 53025/99.

ECtHR, Case Haase v. Germany, application no. 11057/02.

ECtHR, Case Hachette Filipacchi Presse Automobile and Dupuy v. France, application no. 13353/05.

ECtHR, Case Handyside v. The United Kingdom, application no. 5493/72.

ECtHR, Case Hertel v. Switzerland application no. 25181/94.

ECtHR, Case Izci v. Turkey, application no. 42606/05.

ECtHR, Case Jalloh v. Germany, application no. 54810/00.

ECtHR, Case Juppala v. Finland, application no. 18620/03.

ECtHR, Case Laskey, Jaggard $i$ Brown v. The United Kingdom, application no. $21627 / 93$.

ECtHR, Case Magyar Keresztény Mennonita Egyház et al., applications no. $70945 / 11,23611 / 12,26998 / 12,41150 / 12,41155 / 12,41463 / 12$, 41553/12, 54977/12 i 56581/12.

ECtHR, Case Modinos v. Cyprus, application no. No. 15070/89.

ECtHR, Case Nielsen v. Denmark, application no. 10929/84.

ECtHR, Case Norris v. Irland, application no. No. 10581/83.

ECtHR, Case Olsson v. Sweden, application no. 10465/83.

ECtHR, Case Palusiński v. Poland, application no. 62414/00, LEX No. 195832.

ECtHR, Case Tymoshenko et al. v. Ukraine, application no. 48408/12.

ECtHR, Case Cisse v. France, application no. 51346/99.

ECtHR, Case Vergos v. Greece, application no. 65501/01. 
Judgment of 12 December 1996, Oil Platforms (Islamic Republic of Iran v. United States of America).

Judgment of 31 March 2004, Avena and Other Mexican Nationals. 
